\title{
In vitro impact of condensed tannins on the caecal metabolites of chickens*
}

\section{Impacto in vitro de taninos condensados nos metabólitos cecais de frangos de corte}

\author{
Mohammed Munis Dakheel ${ }^{1}$ (D); Mohammed Abdalmalek Ali Al-Bedhawi²; Afnan Ahmed Al-Mnaser ${ }^{3}$; \\ Marina Mora-Ortiz ; Martin John Woodward ${ }^{3}$; Caroline Rymer ${ }^{5}$ (D) \\ ${ }^{1}$ University of Baghdad, College of Veterinary Medicine, Department of Veterinary Public Health, Baghdad, Iraq \\ ${ }^{2}$ University of Baghdad, Institute of Genetic Engineering and Biotechnology, Baghdad, Iraq \\ ${ }^{3}$ University of Reading, Department of Food and Nutritional Sciences, Reading, United of Kingdom \\ ${ }^{4}$ Kings' College London, Department of Twin Research, London, United of Kingdom \\ ${ }^{5}$ University of Reading, School of Agriculture, Policy and Development, Reading, United of Kingdom
}

\begin{abstract}
Tannins are a diverse group of plant phenolic compounds. Condensed tannins (CTs) represent a major subgroup of tannins and were extracted from tilia (Tilia L.) flowers and black locust (Robinia pseudoacacia) leaves. These extracts were examined for their effects on the metabolic profile of chicken caeca. By using in vitro, a nuclear magnetic resonance $\left({ }^{1} \mathrm{H}\right.$-NMR), which was combined with multivariate statistics, the current study was applied for the first time to investigate how three different CT compositions, procyanidins (PC) and/or prodelphinidins (PD) units influenced the metabolic end-products in caecal contents of chickens. In the presence of tannins, glutamate, leucine, lysine, pyroglutamate, phenylalanine, proline, and sarcosine were significantly decreased. CT extracts significantly influenced the fermentation, increasing the concentrations of some fatty acids such as acetate, butyrate, and propionate whereas. In contrast, lactate decreased between the treatments. This study identified the key structural features of CTs that contain either high molar proportions of PD or PC, which might be useful to improve the efficiency of feed utilization in chickens.
\end{abstract}

Keywords: Procyanidins. Prodelphinidins. ${ }^{1} \mathrm{H}$-NMR. Amino acids. Fatty acids. In vitro fermentation.

\section{RESUMO}

Taninos são um grupo diversificado de compostos fenólicos derivados de plantas. Os taninos condensados (TCs) representam o maior subgrupo de taninos extraídos das flores de tília (Tilia L) e de folhas negras (acácia-bastarda). Estes extratos foram examinados para a avaliação dos seus efeitos no perfil metabólico do ceco de frangos de corte. Com o emprego da ressonância magnética nuclear in vitro ( $\left.{ }^{1} \mathrm{H}-\mathrm{NMR}\right)$ combinada com estatística multivariada, o presente trabalho foi aplicado pela primeira vez para investigar como três diferentes composições de TCs, unidades de procianidinas (PC) e/ou prodelfinidinas (PD) influenciariam os produtos metabólicos finais dos conteúdos cecais de frangos de corte. $\mathrm{Na}$ presença de taninos, houve um significativo decréscimo de glutamato, leucina, lisina, piroglutamato, fenilalanina, prolina e sarcosina. Os extratos de TCs influenciaram significativamente a fermentação, aumentando as concentrações de alguns ácidos graxos, tais como o acetato, butirato e propionato, enquanto em contraste, houve um decréscimo do lactato entre os tratamentos. Este trabalho identificou aspectos estruturais chave que os TCs contêm, tanto as altas proporções molares de PD como as de PC, as quais podem ser úteis para aumentar a utilização de alimentos em frangos de corte.

Palavras-chave: Procianidinas. Prodelfinidinas. ${ }^{1} \mathrm{H}-\mathrm{NMR}$. Aminoácidos. Ácidos graxos. Fermentação in vitro.

*This article is part of the thesis: Dakheel, MM. The influence of condensed tannin extracts on gut health in chickens [thesis]. Whiteknights: School of Agriculture, Policy and Development, University of Reading; 2018. Available from: http://centaur.reading.ac.uk/80653/ 


\section{Correspondence to:}

Mohammed Munis Dakheel

University of Baghdad, College of Veterinary Medicine,

Department of Veterinary Public Health

Karrada, Al-Jadriya, Baghdad, Iraq

e-mail:m.m.dakheel@covm.uobaghdad.edu.iq

Received: September 12, 2020

Approved: May 20, 2021

How to cite: Dakheel MM, Al-Bedhawi MAA, Al-Mnaser AA, Mora-Ortiz M, Woodward MJ, Rymer C. In vitro impact of condensed tannins on the caecal metabolites of chickens. Braz J Vet Res Anim Sci. 2021;58:e174733. https://doi.org/10.11606/issn.1678-4456.bjvras.2021.174733

\section{Introduction}

Different dietary interventions in farm animals have been widely investigated to determine their effects on gut function and gut microbial profile and their subsequent effect on animal health (Jana et al., 2015). The emergence of antibiotic resistance by microbes isolated from both humans and animals has led to a ban on the use of antibiotics as growth promoters in the EU and a reduction in the prophylactic use of antibiotics in animal production. This has led to the search for an alternative to antibiotics as growth promoters to support animal health and production (Stokes et al., 2008).

Condensed tannins (CTs) have long been considered as anti-nutritional substances as their presence in animal feeds can have negative effects on animal performance (Lowry et al., 1996). However, recent in vivo and in vitro studies have also shown some beneficial effects of administering these compounds in monogastric feeding (Brenes et al., 2016) and ruminant diets (Quijada et al., 2018). Evidence has emerged that some tannin-containing plants are metabolized by the human gut flora, and there are suggestions that these polyphenolic metabolites may possess beneficial health effects (Calvani et al., 2014). CTs possess many different structures and this paper hypothesizes that it is the concentration and composition of CTs that determines their bioactivity and the yield and composition of metabolic end products.

Caecal bacterial communities and their metabolites are one example of biological activity that characterizes the systemic interactions between the host animal diet and the environment (including the composition of the microbiome) in the gut (Dakheel et al., 2020). These interactions and the resultant metabolite profile may have both beneficial and adverse effects, and thus require comprehensive and systematic profiling (Beckonert et al., 2007).
${ }^{1} \mathrm{H}-\mathrm{NMR}$ spectroscopy can provide an insight into the qualitative and quantitative changes of metabolites of host microbes (Zheng et al., 2011). These metabolites originate from microbial conversion of nutrients and host metabolites in the gut, and once absorbed, are transported throughout the body (Calvani et al., 2014). Therefore, NMR-based metabolic profiling of caecal digesta incubated with CTs is a means of characterizing the biological impact of condensed tannins in the caecum. This is a potentially valuable tool for investigating the mechanism by which different CTs may exert their effects within, for example, the chicken caecum (Dakheel, 2018).

This study explored how CT compositions affected the metabolite profile of caecal digesta (taken from chickens). These data could then be used to determine the potential for adding these compounds to chicken diets as a prophylactic to improve aspects of chicken health and performance.

\section{Materials and Methods}

\section{Preparation of $\mathrm{CT}$ extracts}

The samples were collected from trees, tilia (Tilia L.) flowers, and black locust (Robinia pseudoacacia) leaves around Reading University (Reading, UK). They were then ground to pass through a $1 \mathrm{~mm}$ sieve using an impeller SM1 cutting mill (Retsch, Haan, Germany). These samples, with the highest condensed tannin concentrations, were identified by the HCl-butanol-acetone method (Grabber et al., 2013). Afterward, they were purified by a Sephadex LH-20 column with aqueous acetone (20/80 v/v) (Brown et al., 2017). The CT contents, compositions, and concentrations for each extract were determined using thiolysis analysis and HPLC/MS as described by Gea et al. (2011). Following extraction and purification, these extracts were stored at $-20^{\circ} \mathrm{C}$ in glass vials. The extracts were prepared, as tilia flowers had a mean degree of polymerization, $\mathrm{mDP}$, of 8.9 and the molar percentage of PD was $3.9 \%$, whereas black locust leaves had an $\mathrm{mDP}$ of 9.8 and molar percentage of PD was $74.6 \%$.

\section{Preparation of samples from caecal contents}

Caecal contents were collected from broiler chickens immediately after slaughter. Chickens (Ross $308, \mathrm{n}=8$ ) which had been reared in floor pens on wood shavings and fed a diet based on maize and soybean meal were euthanized by cervical dislocation at 37 days of age and mean body weight of $1.70 \pm 0.200 \mathrm{~kg}$.

The caecal fluid was taken from each caecum of the birds, as quickly as possible, after excision from the carcass by squeezing them into a pre-weighed sterile bottle that was 
then placed immediately inside an anaerobic jar. To ensure sample homogeneity, the caecal fluid from all the birds was pooled, and the contents were mixed by multiple inversions. The anaerobic jars with samples were transferred rapidly to the laboratory where the bottle was weighed. Viade Levure (VL) nutrient broth was added to the caecal contents $(75: 25 \mathrm{v} / \mathrm{w}$ dilution) to produce a caecal slurry.

\section{Incubation of condensed tannins with caecal slurry in vitro}

Duran bottles $(250 \mathrm{ml})$ were inoculated with caecal slurry $(10 \mathrm{ml})$ as prepared above and fresh degassed VL nutrient medium $(50 \mathrm{ml})$ either alone (Control, $20 \mathrm{ml}$ ) or supplemented with CTs of high PD\% from black locust $(0.6 \mathrm{mg} / \mathrm{ml})$ or CTs with high PC\% from tilia flowers $(0.6 \mathrm{mg} / \mathrm{ml})$. Three replicate bottles were prepared for each treatment. The $\mathrm{pH}$ value was adjusted to $\mathrm{pH}$ 6.5 before rapid transfer to an anaerobic chamber (Whitley MG1000 anaerobic workstation, Don Widley, England, UK), where the temperature was maintained at $41^{\circ} \mathrm{C}$. The model was run as a closed fermentation system, meaning that air exchange was prohibited (Dakheel, 2018).

During the incubation, a sample $(3 \mathrm{ml})$ of incubation medium was taken from each bottle at $0,10,24$, and $48 \mathrm{~h}$. These samples were then snap-frozen in liquid nitrogen before being stored $(-80)^{0} \mathrm{C}$ pending analysis by ${ }^{1} \mathrm{H}-\mathrm{NMR}$.

\section{Setup of the NMR instrument}

The samples were analyzed by $1 \mathrm{D}$ Nuclear Overhauser Enhancement Spectroscopy (NOESY-1D); i.e. by ${ }^{1} \mathrm{H}-\mathrm{NMR}$ instrument (Bruker Advance III $700 \mathrm{MHz}$, Billerica, MA, USA). The sources were acquired using a Bruker-FID pulse sequence to limit signal contribution. For each sample, the acquisition was 256 scans (as transients or scans) and recorded as 32,768 data points over a spectral width of $9803.922 \mathrm{~Hz}$ as for NOESY-1D. The temperature was $299.98 \mathrm{~K}$ at $700.19 \mathrm{MHz}$ magnetic frequency at time domain 16,384 points. This NOESY-1D was achieved for each experiment on one representative sample for metabolic identification purposes (Le Roy et al., 2016).

\section{Sample preparation for NMR analysis}

Following the method described by Le Roy et al. (2016), the samples (stored at $-80^{\circ} \mathrm{C}$ ), which had been taken from the incubation of the caecal slurry, were thawed at room temperature and then vortexed before being centrifuged $(10,000 \mathrm{~g})$ for $10 \mathrm{~min}$. Then, $400 \mu \mathrm{l}$ of the supernatant was transferred to a sterile microfuge tube to which $200 \mu \mathrm{l}$ phosphate buffer solution (g/l D $2 \mathrm{O}: \mathrm{Na}_{2} \mathrm{HPO}_{4} 28.85$, $\mathrm{NaH}_{2} \mathrm{PO}_{4} 28.85,2,2$ ', 3, 3'-tetradeuteropropionic acid
$0.172, \mathrm{NaN}_{3} 0.193$ ) was added. Afterward, these samples were vortexed and centrifuged at 10,000 $\mathrm{g}$ for $10 \mathrm{~min}$, and then $550 \mu$ of the supernatant was transferred to a $5 \mathrm{~mm}$ internal diameter NMR tube.

\section{Processing the data for analysis}

All spectral peaks were measured using MestReNova software (Mnova, version: 11.0.3-18688; (c) 2017 Mestrelab Research S.L., Santiago de Compostela, Spain). The raw data were dragged from a file 'fid' that was generated by the NMR computer software. These files were then automatically transformed into frequency domains (Dieterle et al., 2006).

NMR spectra were phased, processed to realign spectrum phasing calibration on TSP at $(\delta 0.00)$, and baseline correction by using MestReNova. Stacked spectra were imported into MATLAB version R2017a (MathWorks, Inc., Natick, MA, USA), where spectra were eliminated (before $\delta 0.5$ and after $\delta 9.5)$ to delete useless information and avoid data bias. Also, the region containing the water peak was deleted between $\delta 4.8$ and $\delta 5.0$ (Mora-Ortiz et al., 2019a).

Metabolic variations existing between the treatments were examined in MATLAB equipped with Korrigan Toolbox version 0.1 (Korrigan Sciences Ltd., U.K.) using a multivariate statistical approach. The pipeline followed included a preliminary analysis of the variability using principal component analysis (PCA), where potential outliers were identified. This was followed up by orthogonal projections to latent structure discriminant analysis (O-PLS DA) to investigate the effects of time and treatment. O-PLS DA $R^{2} Y$ values close to 1 were indicative of a good model, with positive $Q^{2} Y$ values and an overfit smaller than 50\%. PCA score plots and O-PLS DA correlation plots were also produced to visualize differences in the metabolome between treatments and identify significant metabolites. These data were analyzed as previously reported by (Mora-Ortiz et al., 2019b). Each peak was then related to a metabolic product by reference to the human metabolome database (HMDB). Once identified, these metabolic products were then analyzed by Chenomx software (NMR suit; version 8.31; ( ) 2001-2017 Chenomx Inc., Edmonton, AB, Canada) and ChemBioDraw software (version: 14.0.0117; @ 1998-2014, PerkinElmer Inc., MA, USA) to record the concentrations of metabolites.

\section{Results and Discussion}

\section{Effects of CTs on metabolic products of caecal slurry in vitro}

${ }^{1} \mathrm{H}$-NMR spectra of the caecal slurry fermentation samples taken from control and CT treated at different time points 
$(0,10,24$, and $48 \mathrm{~h})$ were determined. The results showed that there were no significant differences in concentrations of metabolites between $24 \mathrm{~h}$ and $48 \mathrm{~h}$ incubations. Thus, the endpoint of fermentation was reached by $24 \mathrm{~h}$. As anticipated the spectra at time-point $0 \mathrm{~h}$ were similar for all samples, although new peaks were recognized in the tannin treatment groups related to the $\mathrm{CT}$ composition with the aromatic area of the spectra ( $>\delta 5.5$ ) showing the signals of CT residues in the treated groups, which were absent in the control (Mora-Ortiz et al., 2019a).

The signals at $\delta 5.90$ to $\delta 7.50$ illustrated the presence of PC or PD units (dependent on the particular CT source) as well as other compounds that were present in the CTs. Moreover, the signals that appeared at $\delta 4.50$ are typical of the presence of the PC/PD subunits catechin/epicatechin or gallocatechin/epigallocatechin, respectively, and the region between $\delta 2.50$ and $\delta 2.80$ is due to other signals of flavan-3-ol units (Fryganas et al., 2018). ${ }^{1} \mathrm{H}-\mathrm{NMR}$ spectra-based metabolic profiling allowed monitoring and determination of the change in concentrations of some important metabolic end compounds that could play a role in the energy metabolism of the microbes (Le Roy et al., 2016). These metabolites were affected by the presence or absence of CT (Zheng et al., 2011).

\section{Amino acids}

This study summarizes the effect of CT on the caecal metabolic profile. The addition of CT was characterized by low concentrations of amino acids, particularly glutamate, pyroglutamate, phenylalanine, lysine, and leucine. This result also showed significant differences $(P$-value $\leq 0.05)$ associated with a decrease in the concentrations of these amino acids in the caecum containing CTs at different times compared to controls. Anaerobic bacteria could utilize glutamate, which is an important amino acid that participates actively in the TCA cycle, into fatty acids such as acetate, butyrate, and other molecules e.g. ammonia. Nonetheless, this amino acid can also contribute to transamination with pyruvate, which is fermented into fatty acids by gut microbes and reduces this amino acid (Meister, 2012). Further, phenylalanine, which is an aromatic amino acid that is produced from bacterial degradation showed a significant decrease $(\mathrm{P} \leq 0.05)$ at different time points. Gut microbiota such as Bacteroidetes spp. and Lactobacilli spp. may be involved in this process (Fuchs et al., 2014). As observed recently (Amorim Franco \& Blanchard, 2017), branched-chain amino acids can undergo oxidative transamination at an appreciable rate by an enzyme that is called aminotransferase. This enzyme, thus, is responsible for the final step in the biosynthesis of these amino acids such as leucine, isoleucine, and valine, in bacteria. This study showed that the decrease of these amino acids also presented evidence of amino acids transamination into pyruvate, which can be fermented by gut microbes into different fatty acids such as propionate, butyrate, and acetate. Therefore, the content of CT in the animal diet should be considered.

\section{Fatty acids}

In contrast, the concentrations of some fatty acids such as acetate, butyrate, and propionate were significantly increased $(P$-value $\leq 0.05)$ in fermentations containing CTs compared with the control at $10 \mathrm{~h}$ and $24 \mathrm{~h}$, perhaps suggesting that fermentation of carbohydrates had been increased. However, the fermentation of some shortchain fatty acids was possibly interrupted in the presence of CTs by affecting the succinate pathway, which is placed into one of the most important cyclic pathways in metabolism (Neis et al., 2015), while acetate is the end product of anaerobic fermentation (Macfarlane \& Macfarlane, 2012). Lactate concentrations also decreased gradually in the CT treatments compared to the controls $(P$-value $\leq 0.05)$. These findings might suggest that gut microbes respired aerobically to produce the anticipated end products of energy metabolism. This result seems to indicate that both CT compositions could encourage the proliferation of lactic acid-producing microorganisms and interrupt the TCA as mentioned previously (Tjahjani, 2017). Besides, lactic acid tends to reduce $\mathrm{pH}$ more than other fatty acids. Lactate produced by lactic acid bacteria is normally rapidly absorbed from the intestine or used as a substrate for lactate-utilizing bacteria (Rinttila \& Apajalahti, 2013). Further microbiological studies are needed to investigate the relationship between individual fatty acids and bacterial populations in the presence of different CT types.

\section{Carbohydrates}

Figures 1 and 2 illustrate more details for the key metabolites that demonstrate significant differences at S-line plot, which contributed to this discrimination between the interaction of the treatments and different time-points (after $10 \mathrm{~h}$ and $24 \mathrm{~h}$ ) in the presence or absence of CT compositions, i.e. high PC and PD. Further, a color code indicates the weights of the discriminatory variables, as the peak color gradually changes from blue to red, the absolute value of the correlation coefficient increases, indicating the resonances were important for discriminating metabolite profiles of pairwise analyses (Mora-Ortiz et al., 2019a, 2019b). 

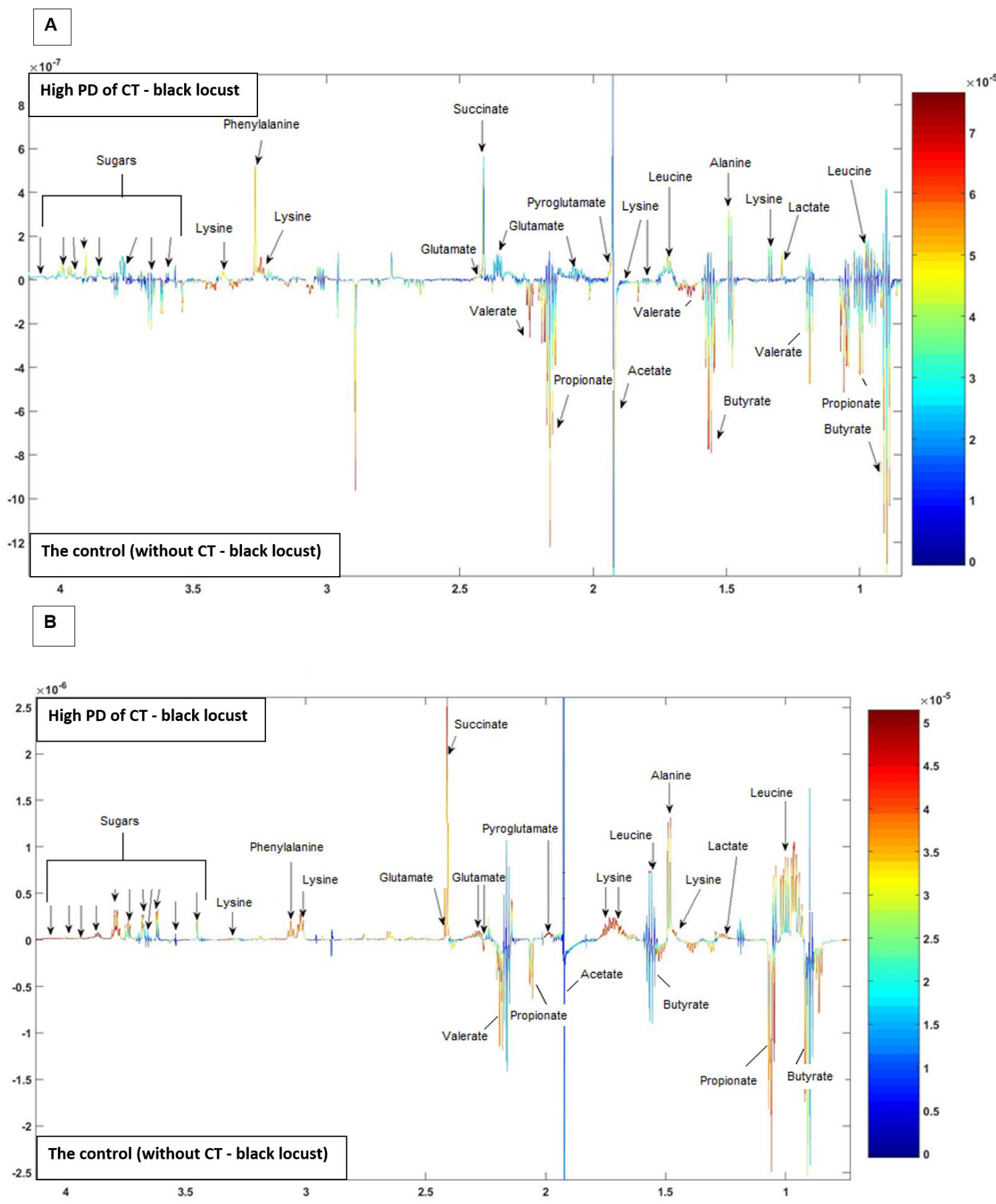

Figure 1 - The color plot of ${ }^{1} \mathrm{H}-\mathrm{NMR}$ spectra highlights the most important metabolites of caecal contents of the chickens for the differentiation between controls (bottom) and treated with or without CT - black locust (high PD at $0.6 \mathrm{mg} / \mathrm{ml}$ ) (top) after (A) $10 \mathrm{~h}$ and (B) $24 \mathrm{~h}$.

Also, carbohydrates such as mannitol, glucose, fructose, lactose, and galactose demonstrated slight concentration changes between the treated groups. However, the statistical analysis of these carbohydrates did not show any significant differences $(P$-value $\geq 0.05)$ between the interaction of times and treatments, but some of them, e.g. mannitol, glucose, fructose, lactose, and galactose, measured a significant difference $(P$-value $\leq 0.05)$ at $24 \mathrm{~h}$ only. Beneficial bacteria in the gut are susceptible to changes in dietary carbohydrates, which in turn affect caecum fatty acid concentrations.
Once carbohydrate sources are exhausted in the caecum, sources of protein material are fermented and metabolized to energy (Niba et al., 2009).

Finally, the current study showed the effects of both CTs supplementation on metabolic end-products and these impacts might be related to changes in gut microbiota. Also, this study indicated that PD and PC types of CTs have the same effects on the caecal contents. More specific studies are required to clarify how these CTs influence gut microbiota in vitro and in vivo. 

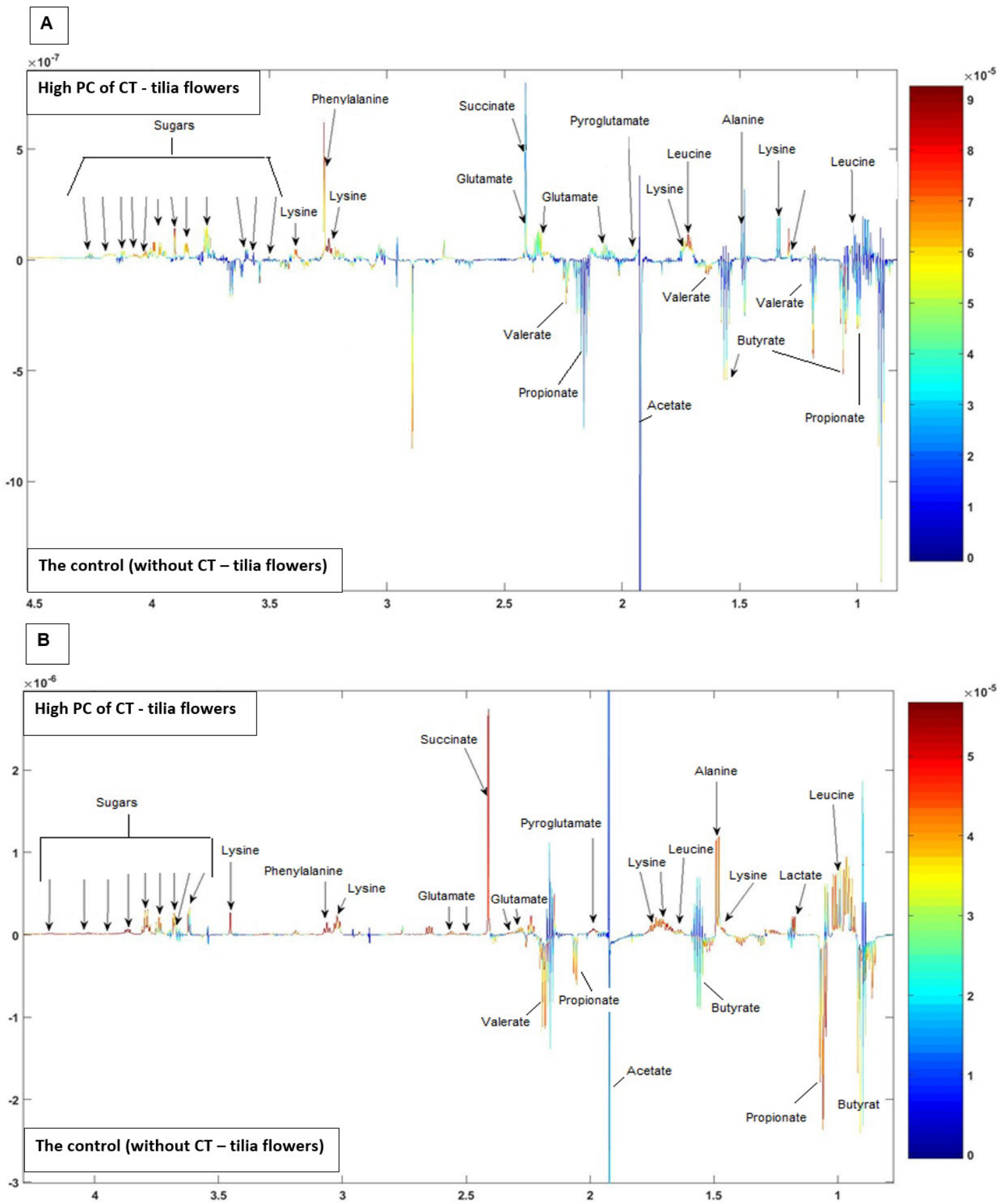

Figure 2 - The color plot of ${ }^{1} \mathrm{H}-\mathrm{NMR}$ spectra highlights the most important metabolites of caecal contents of the chickens for the differentiation between controls (bottom) and treated with or without CT- tilia flowers (high PC at $0.6 \mathrm{mg} / \mathrm{ml}$ ) (top) after (A) $10 \mathrm{~h}$ and (B) $24 \mathrm{~h}$.

\section{${ }^{1} \mathrm{H}$-NMR spectra of caecal contents}

Unsurprisingly, the addition of CT to the incubation medium resulted in NMR peaks associated with different CT residues (Fryganas et al., 2018). This indicated that the PC and PD were metabolized to a limited extent and undigested CTs were fermented in caecal content in this in vitro experiment. To identify metabolic variation based on correlation coefficient values between the sample's assignment of spectral lines over time between the different treatments for all time-points collected was applied to metabolic profiles (Dakheel, 2018).

Figure 3 provides an overview of the PCA that is based on OPLS to statistically draw the graphs from a class model that examined the homogeneity among the samples. The metabolic profile of the data resulted in $R^{2} Y(0.77)$ and $\mathrm{Q}^{2} \mathrm{Y}(0.54)$ values of $63 \%$ for the first two components, which are illustrated in a color plot to describe the metabolic variability between all groups at different time points. 


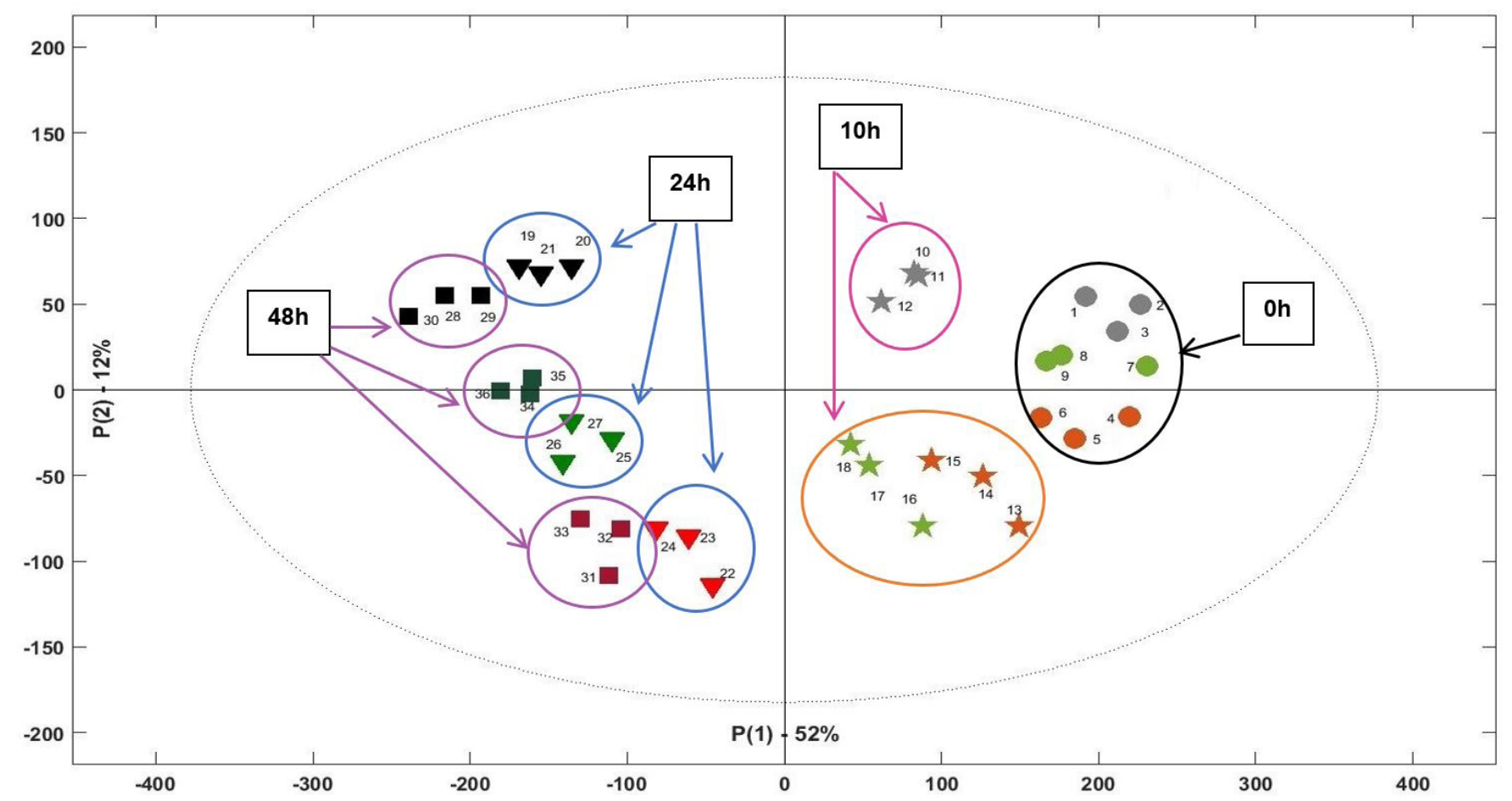

Figure 3 - Principal component analysis (PCA) - score plot obtained from the ${ }^{1} \mathrm{H}-\mathrm{NMR}$ spectra of caecal contents of the chickens that were treated with CTs of either high PD $\%$ or high PC $\%$ for different time-points; $\mathrm{R}^{2}=0.77, \mathrm{Q}^{2}=0.54$. Circles indicate the treatments at $0 \mathrm{~h}$, stars indicate the treatments at $10 \mathrm{~h}$, triangles indicate the treatments at $24 \mathrm{~h}$ and squares indicate the treatments at $48 \mathrm{~h}$; (Red = high PD\% group; Green = high PC \% group; Black = controls).

An OPLS plot discriminated between the control samples and the CT samples using time point as a predictor, at time point $10 \mathrm{~h}$ and $24 \mathrm{~h}$. These plots showed that they are a good model and predictive ability in the concentrations of metabolites between treated and untreated groups. These differences have been plotted in colors at different time points. In these models, a clear separation was evident based on the different CT types and controls within the time recorded.

\section{Conclusion}

This study also indicated significant changes in some important metabolites, such as amino acids, occurred at different time points. The most obvious finding was that the stimulation of fermentation with both CT types affected the fatty acids, especially acetate, butyrate, and propionate were significantly increased, compared to the control at $10 \mathrm{~h}$ and $24 \mathrm{~h}$. More specific studies are required to understand the fate of CTs and clarify how they affect intestinal microbiota in vitro and in vivo.

The positive aspects of this in vitro research favored describing in a precise way the performance of the CTs in the cecum of broilers, with no interference of its digestion in other organs. However, the negative aspect is the work would be evaluated to the potential use of CTs as prophylactics regarding the health and performance of broilers, which will probably compose a new work. Therefore, further research will be necessary to investigate which pathogens would be sensitive to such metabolites.

\section{Conflict of Interest}

The authors declare that there is no conflict of interests.

\section{Ethics Statement}

MOHSER in Iraq provided an ethical approval from the Research Ethical Committee. The authors have received ethical approval from the University of Baghdad/ College of Veterinary Medicine; all methods were applied on the animals were in accordance with the Animal Care \& Use Committee's guidelines.

\section{Acknowledgements}

The authors thank the Ministry of Higher Education and Scientific Research and Veterinary Medicine College at Baghdad University/ Iraq, which provided support for this investigation. Thanks to the School of Agriculture, Policy, and Development and the School of Chemistry, Food, and Pharmacy at the University of Reading for helping us to achieve the study. Also, thanks to Korrigan Sciences Ltd., UK, for providing the Korrigan Toolbox version 0.1 . 


\section{References}

Amorim Franco TM, Blanchard JS. Bacterial branchedchain amino acid biosynthesis: structures, mechanisms, and drugability. Biochemistry. 2017;56(44):5849-65. http:// dx.doi.org/10.1021/acs.biochem.7b00849. PMid:28977745.

Beckonert O, Keun HC, Ebbels TM, Bundy J, Holmes E, Lindon JC, Nicholson JK. Metabolic profiling, metabolomic and metabonomic procedures for NMR spectroscopy of urine, plasma, serum and tissue extracts. Nat Protoc. 2007;2(11):2692-703. http://dx.doi.org/10.1038/nprot.2007.376. PMid: 18007604.

Brenes A, Viveros A, Chamorro S, Arija I. Use of polyphenolrich grape by-products in monogastric nutrition. A review. Anim Feed Sci Technol. 2016;211:1-7. http://dx.doi. org/10.1016/j.anifeedsci.2015.09.016.

Brown RH, Mueller-Harvey I, Zeller WE, Reinhardt L, Stringano E, Gea A, Drake C, Ropiak HM, Fryganas C, Ramsay A, Hardcastle EE. Facile purification of milligram to gram quantities of condensed tannins according to mean degree of polymerization and flavan-3-ol subunit composition. J Agric Food Chem. 2017;65(36):8072-82.

Calvani R, Brasili E, Praticò G, Sciubba F, Roselli M, Finamore A, Marini F, Marzetti E, Miccheli A. Application of NMRbased metabolomics to the study of gut microbiota in obesity. J Clin Gastroenterol. 2014;48(Suppl 1):S5-7. http://dx.doi. org/10.1097/MCG.0000000000000236. PMid:25291128.

Dakheel MM, Alkandari FA, Mueller-Harvey I, Woodward MJ, Rymer C. Antimicrobial in vitro activities of condensed tannin extracts on avian pathogenic Escherichia coli. Lett Appl Microbiol. 2020;70(3):165-72. http://dx.doi.org/10.1111/ lam.13253. PMid:31782190.

Dakheel MM. The influence of condensed tannin extracts on gut health in chickens [dissertation]. Reading: University of Reading; 2018.

Dieterle F, Ross A, Schlotterbeck G, Senn H. Probabilistic quotient normalization as robust method to account for dilution of complex biological mixtures. Application in 1 H NMR metabonomics. Anal Chem. 2006;78(13):428190. http://dx.doi.org/10.1021/ac051632c. PMid:16808434.

Fryganas C, Drake C, Ropiak HM, Mora-Ortiz M, Smith LM, Mueller-Harvey I, Kowalczyk RM. Carbon-13 crosspolarization magic-angle spinning nuclear magnetic resonance for measuring proanthocyanidin content and procyanidin to prodelphinidin ratio in sainfoin (Onobrychis viciifolia) tissues. J Agric Food Chem. 2018;66(16):4073-81. http:// dx.doi.org/10.1021/acs.jafc.8b01215. PMid:29631396.

Fuchs S, Behrends V, Bundy JG, Crisanti A, Nolan T. Phenylalanine metabolism regulates reproduction and parasite melanization in the malaria mosquito. PLoS One. 2014;9(1):e84865. http://dx.doi.org/10.1371/journal. pone.0084865. PMid:24409310.

Gea A, Stringano E, Brown RH, Mueller-Harvey I. In situ analysis and structural elucidation of sainfoin (Onobrychis viciifolia) tannins for high-throughput germplasm screening. J Agric Food Chem. 2011;59(2):495-503. http://dx.doi. org/10.1021/jf103609p. PMid:21175139.

Grabber JH, Zeller WE, Mueller-Harvey I. Acetone enhances the direct analysis of procyanidin-and prodelphinidin-based condensed tannins in Lotus species by the butanol-HCliron assay. J Agric Food Chem. 2013;61(11):2669-78. http:// dx.doi.org/10.1021/jf304158m. PMid:23383722.

Jana A, Adak A, Haider SK, Das A, Paul T, Mondal KC, Mohapatra PK. A new strategy for improvement of tamarind seed based chicken diet after microbial detannification and assessment of its safety aspects. Acta Biol Szeged. 2015;59(1):1-9.

Le Roy CI, Mappley LJ, La Ragione RM, Woodward MJ, Claus SP. NMR-based metabolic characterization of chicken tissues and biofluids: a model for avian research. Metabolomics. 2016;12(10):157. http://dx.doi.org/10.1007/ s11306-016-1105-7. PMid:27729831.

Lowry JB, McSweeney CS, Palmer B. Changing perceptions of the effect of plant phenolics on nutrient supply in the ruminant. Aust J Agric Res. 1996;47(6):829-42. http:// dx.doi.org/10.1071/AR9960829.

Macfarlane GT, Macfarlane S. Bacteria, colonic fermentation, and gastrointestinal health. J AOAC Int. 2012;95(1):5060. http://dx.doi.org/10.5740/jaoacint.SGE_Macfarlane. PMid:22468341.

Meister A. Biochemistry of the amino acids. USA: Elsevier; 2012. 485 p.

Mora-Ortiz M, Nuñez Ramos P, Oregioni A, Claus SP. NMR metabolomics identifies over 60 biomarkers associated with Type II Diabetes impairment in $\mathrm{db} / \mathrm{db}$ mice. Metabolomics. 
2019a;15(6):89. http://dx.doi.org/10.1007/s11306-0191548-8. PMid:31179513.

Mora-Ortiz M, Trichard M, Oregioni A, Claus SP. Thanatometabolomics: introducing NMR-based metabolomics to identify metabolic biomarkers of the time of death. Metabolomics. 2019b;15(3):37. http://dx.doi.org/10.1007/ s11306-019-1498-1. PMid:30834988.

Neis EP, Dejong CH, Rensen SS. The role of microbial amino acid metabolism in host metabolism. Nutrients. 2015;7(4):2930-46. http://dx.doi.org/10.3390/nu7042930. PMid:25894657.

Niba AT, Beal JD, Kudi AC, Brooks PH. Bacterial fermentation in the gastrointestinal tract of non-ruminants: influence of fermented feeds and fermentable carbohydrates. Trop Anim Health Prod. 2009;41(7):1393-407. http://dx.doi. org/10.1007/s11250-009-9327-6. PMid:19283504.

Quijada J, Drake C, Gaudin E, El-Korso R, Hoste H, MuellerHarvey I. Condensed tannin changes along the digestive tract in lambs fed with sainfoin pellets or hazelnut skins. J Agric Food Chem. 2018;66(9):2136-42. http://dx.doi. org/10.1021/acs.jafc.7b05538. PMid:29424229.
Rinttilä T, Apajalahti J. Intestinal microbiota and metabolites: implications for broiler chicken health and performance. J Appl Poult Res. 2013;22(3):647-58. http://dx.doi.org/10.3382/ japr.2013-00742.

Stokes DJ, Kelly AF, Gould SW, Cassar CA, Fielder MD. The withdrawal of antimicrobial treatment as a mechanism for defeating resistant microorganisms. FEMS Immunol Med Microbiol. 2008;53(3):300-5. http://dx.doi.org/10.1111/j.1574695X.2008.00429.x. PMid:18554301.

Tjahjani S. Antimalarial activity of Garcinia mangostana $\mathrm{L}$ rind and its synergistic effect with artemisinin in vitro. BMC Complement Altern Med. 2017;17(1):131. http:// dx.doi.org/10.1186/s12906-017-1649-8. PMid:28241761 .

Zheng C, Zhang S, Ragg S, Raftery D, Vitek O. Identification and quantification of metabolites in $1 \mathrm{H}$ NMR spectra by Bayesian model selection. Bioinformatics. 2011;27(12):163744. http://dx.doi.org/10.1093/bioinformatics/btr118. PMid:21398670.

Financial Support: No financial support received. 